\title{
Unfavorable Clauses in International Investment Contracts of Aceh Province, Indonesia
}

\author{
Sanusi Bintang \\ Department of Private Law, Faculty of Law, Syiah Kuala University (UNSYIAH), Banda Aceh, Indonesia.
}

\begin{abstract}
Ideally international investment contracts regulate rights and obligations of parties in balance. In reality, how ever, this cannot be fully achieved by parties. Unfavourable clauses to state/region are existed. These clauses, including but not limited to, choice of foreign/international arbitration abroad, license enrollment/facility, exclusivity of cooperation, long-term contracts, choice of foreign domestic law, waiver of immunity, and confidentiality/intellectual property protection. Understanding the nature of these clauses is important for considerations in negotiation or renegotiation of international investment contracts. How ever, only by understanding these clauses without understanding the whole contract clauses, is not enough for judging balance of each contract. The whole contract clauses includes both unfavorable and favorable have to be compared and analyzed together. This paper, how ever, concentrates mainly on unfavourable clauses to host state/region as a party to international investment contracts.
\end{abstract}

Key words: Aceh Province, Indonesia, International Investment Contracts, Unfavorable Clauses.

\subsection{Background}

\section{INTRODUCTION}

The parties to international investment contracts are foreign or international investors and host country state/region. Therefore, it is also called as investor-state contracts or state contracts. These type of contracts in Indonesian law fall under classification of specific contracts. Specific because they have distinctive characteristics, among others, higher involvevement of state/region in the contractual process when compare to other contracts in general. ${ }^{\mathrm{i}}$ Therefore, they have specific law (lex specialis) as opposed to generic law (lex generali). When these to kinds of law in conflict, the specific law dictates.

The international investement contracts contains various clauses which is made based on parties consent. This clauses are parts of international investment contract law. They are the product of long negotiations between parties, which then be signed by the parties. In other words, the clauses are made based on parties meeting of minds. This practice is in accordance with principle of party autonomy. The availability of consent, among others, can be proved from the availability of signatures of parties at the closing of operative parts in contracts. These signatures imply that the parties have agreed all contract clauses. The whole process of the international business transactions inludes 3 (there) phases: preparation, performance, and enforcement. The signatures inlude in the preparation phase. ${ }^{\text {ii }}$

The elaboration of principle of party autonomy in content of contracts often can be seen since formulation of recitals which states that both parties agree to be bounded by terms and conditions of contracts. In common law system, the availability of recitals in the contract framework is also aimed to show that one element for validity of contracts, called consideration, is fulfilled. Wheres, in civil law system, including in Indonesian law, consideration is not consider as an element for the validity of contracts. How ever, within the field of international contracts understanding both common law and civil law perspectives is important. This is because based on the doctrine choice of law, the applicable law to international contracts, may be any national law from any legal system.

Contracts are made based on principle of party autonomy or also called principle of freedom of contract, ${ }^{\mathrm{iii}}$ then becom valid and enforceable based on principle of pacta sunt servanda ${ }^{\mathrm{iv}}$ Therefore, the contract first should be materially made in accordance with the principle of party autonomy, and then become formally valid. As consequences, both parties must perform all rights and obligation in the contracts. Principle of pacta sunt servanda means contract is applicable similar to an act or legislation. Those who breach the contracts face the private sactions, among others, paying damages or compensation. Compare to principle of freedom of contract which is already universal recognition and application, the principle of pacta sunt servanda eventhough has also universal recognition and application for contracts in general, but still not as important in international investment contracts.

The elaboration of the principle of pacta sunt servanda in drafting international investment contracts can be found in boiler plate clauses. For example in formulation of amandment clause, assignment clause, 
immunity clause, and entire contract clause. Amandment clause states that the contracts clauses can only be amanded by the consent of both parties. Assignment clause states that either party cannot assign the contract to third party, without consent by both parties. Immunity clause states that the state/region party in the context of this contract will act fully in commercial capacity (jure gestiones), and not in sovereign capacity (jure emperii). Entire agrement clause states that the contract is the last or the only form, incorporating all other previous agreements, both written and unwritten, therefore it becomes preference. All these boiler plate clauses connotates the eleboration and application of principle of pacta sunt servanda.

Both principle of party autonomy and principle of pacta sunt servanda are aimed at achieving legal certainty. This can be achieved through obligation for both parties to perform all rights and obligations as stipulated in contract clauses. Neither party can terminate the contracts, except on the consent of both. Therefore, through the application of these principles the parties can anticipate business opportunity and prevent possible lost in the future.

The importance of principle of party autonomy and principle of pacta sunt servanda were supported by philosophy of classical contract theory, which prefer the fulfilment of legal certainty of contracts. This theory also called contract formalism. Eventhough, in theory both parties can benefitted from this reasoning, in practice of international investment contracts, it is favorable more for one party only, that is international investors. This because on the whole, the international investors gain more protection by conctract clauses, rather than that of house state/region. Therefore, the contracts becomes imbalance.

International investors have greater interest in performance of the contracts. Therefore, legal certainty is more for the interest of investors. To be balance, the contract should also elaborate and apply principles of justice and fairness. These principles may have different names in different countries. For example in Indonesian adat law and Islamic law called principle of equilibrium, in civil law system called principle of good faith, in American common law called principle of unconsionability, in Dutch law called principle of reasonableness and fairness, and in European contract law called principle of proportionality.

Principles of justice and fairness is aimed at achieving justice. ${ }^{v}$ It can be used to balance the interests of both parties in international investment contracts. In Indonesia, for example, the legal basis for principle of good faith is regulated in article 1338 paragraph (3) Indonesian Civil Code (ICC). Whereas, in transnational law the legal basis for principle of good faith and fair dealing is regulated under article 7.1 UNIDROIT Priciples on International Commercial Contracts (UPICC).

The application of principles of justice and fairness is aimed at balancing the interest of both parties. This is important because up to present many developing countries feel inbalance contractual reletions with international investors from developed countries. This can bee seen in formulating rights and obligations of the parties in operative part of international investment contracts. It is often contractual clauses are more favorable to international investors than to house state/region. ${ }^{\mathrm{vi}}$

The fact that the contracts clauses inbalance only, how ever, is not enough as reasons for termination and adaptation of international investment contracts. It needs additional reasons, for example, as stipulated in European contract law principles. ${ }^{\text {vii }}$ Therefore, after proving the inbalance, the next step needs to show that the imbalance is significant. In other words to be able to terminate or adapt contracts, the clauses shoud be expoitative. It means that a party to the contracts obtaines gross profit by exploiting another party.

The requirement for the availability of expoitative contracts, among others, regulates in UPICC. UPICC chooses term gross disparity. Aticle 3.10 paragraph (1) UPICC provides that "A party may avoid the contract or individual term of it...unjustifiably gave other party an excessive advantage..." When this requirement is fulfilled, based on the request of the aggrieved party, courts or arbitration can adapt the whole or part of the contract to be in line with resonable and fair business standards.

\subsection{Research Problem}

The main research problem in this research is formulated as follows: Whether international investment contracts of Aceh Province contain unfavorable clauses to house state/region party?

\subsection{Research Method}

This research utilizes doctrinal legal research method. The research was conducted through retrieving and finding relevant legal authorities. First, primary mandatory legal authorities and primary nonmandatory legal authorities. In Indonesian civil law system, the primary mandatory legal authorities includes contracts, legislations, and regulations. Primary nonmandatory legal authorities includes judicial inteprtetations. The main focus of the authortities is international investment contracts of Aceh Province. Researcher collect, study, and analize in detail clauses in operatif parts of 6 (six) selected international investment contracts of the Province of Aceh, Indonesia.

Second, secondary authority. The secondary authority includes journal articles, law books, research paper, and the like. This secondary authority provides expert analysis on various primary authority on relevant 
legal issues. The secondary legal authorities is important for interpretation or legal reasoning of mandatory authorities to be used in analyzing the legal issues or in answering the research questions.

Both mandatory and secondary legal authorities ware obtained through retrieving and finding both printed and electronic legal information sources. The printed legal information source was mainly found in law libraries. The electronic information source was found through Internet access. This includes yahoo.com and google scholars. The most frequently used legal database was Free Full-Text Online Law Review/Journal Search.

The presentation of the article is systematiclaly organized as follows. Firstly, introduction is as above. Secondly, discussion to analyze in detail the main legal issue presented. The broad main legal issue is broken down into unfavorable clauses and favorable clauses. Deeper legal analysis is given to unfavorable clauses. Finally, before references conclusion is presented.

\section{DISCUSSION}

\subsection{Unfavorable Clauses}

2.1.1 Choice of Foreign/International Arbitration Abroad

Parties to international investment contract based on doctrine of international private law is basically free to choose any dispute settlement mechanism. They can choose court or arbitration. They can do that with or without using alternative dispute resolution before choosing court or arbitration. The alternative dispute resolution includes negotiation, mediation, and consiliation. Where the parties do not choose arbitration, the case automatically falls within court jurisdiction. Here, the parties can bring the case to civil court in jurisdiction as chosen by parties in contract clauses or after dispute arises. In case no choice of law by the parties, as ascertained by doctrine of international private law. ${ }^{\text {viii }}$

Almost all contracts studied choose out of court settelements. This is possible based on Act Number 30 of 1999 on Arbitration and Alternative Dispute Resolution (AA \& ADR) and New York Convention of 1958 on Recognition and Enforcement of Foreign Arbitral Awards. How ever, there are variations in formulating the dispute settlement clauses. First, those who used alternative dispute resolution as the first method of dispute settlement, before they go to arbitration process. Second, those who directly go to international arbitration as the only dispute settlement mechanism. Even though, contracts do not have arbitration clause (pactum de compromittendo), the parties still can choose arbitration after dispute arises (acta compromis).

The parties can choose various international arbitration centers and rules of procedure. These include Center of Arbitration of International Convention on the Settelement Investment Disputes (ICSID), Center of Arbitration of International Chamber of Commerce (ICC), and Center of Arbitration of United Nations Convention on International Trade Law (UNCITRAL). Besides, the contracts choose Singapore International Arbitration Center (SIAC), London International Arbitration Center, and Indonesia National Arbitration Center, which in Indonesian named with Badan Arbitrase National Indonesia (BANI).

Each arbitration center has its own procedural rules with is basically simpler than national civil court procedure. It is one of the reason why majority of international investment contracts choose arbitration as method of dispute settelement. ${ }^{\text {ix }}$ This flexibility made possible the case be settled with fast, efficient, neutral, and fair manner.

Instead of its flexibility, the choose of foreign or international arbitration abroad is basically unfavorable against the interests of house state/region party. On the other hand, it is favorable for international investors. For house state/region party It is unfavorable because has less familiarity with rules of procedure and language used in arbitration process. It also needs more cost for accomodation and transportation to location of arbitration abroad during the process or arbitration. Therefore, it is better to choose arbitration center in Indonesia or in Indonesian neighboring countries. ${ }^{\mathrm{x}}$

\subsubsection{Licensing Enrollment/Facility}

According to Act Number 25 of 2007 on Investment (AI) that each international investor before permitting to operationally perform the investment activities should obtain related investment licences. For Indonesian government it is needed as an intrument for controlling and supporting the investment activities. How ever, unclear and overregulated licensing, and birocratic practices become problems. It cost money and special efforts from international investment companies. Therefore, it is become a hindrance and inefficient, particularly if international investors have to face alone.

To settle the problems, and to achieve efficient and effective investment, international investors share this kind of tasks to house state/region party. Here, the state/region has a dual roles, as regulator or public actor and as commercial actor. The state/region party has more experience on dealing with domestic beurocracy and has better networks from central to local government institutions and officials. In other words, state/region party has closer link to beurocracy and more understood in dealing with local culture. This practice, how ever, can create discrimination and unneceasary privillages for international investors, compare to domestic investors. It also opens opportunity for corruption and collition practices. 
The nature of this clause is favourable for international investors. How ever, it is unfavorable to state/region party. Therefore, it needs to be reviewed more thourougly when drafting international investment contracts so that it does not to exceed limit than necessary. Here, prudential and proportional practices is needed.

\subsubsection{Exclusivity of Cooperation}

It is often international investment contracts have exclusivity clause. This clause is important for international investors, as efforts to obtain certainty and predictability of cooperation. It can maintain their busniness opportunity, and prevent their future loss.

The purpose of this clause, among others, to prevent state/region party to plan and perform negotiation with third parties on similar investment. For example, a clause states that for certain duration after contract is signed, the state/region party is prohibitted to perform negotiation with any party related to the international business transactions. If this clause is not available, the cooperation becomes nonexclusive. Here, state/region party eventhough has signed the contract, to a certain extent still can negotiate the project with others. This creates risks to international investors.

The availability of exclusivity clause, if not limited, is unfavorable for state/region party. Therefore, it needs to be considered when negotiating or drafting international investment contracts. This because when it is used unproperly. For example with the intention not to perform the project within a reasonable time, it becomes unfavorable to state/region party. The state/region party is prevented from the efforts to select the most sertious or the best suitable international investors.

\subsubsection{Long Term}

Duration of contracts has economic value. It is often, the longer its duration, the higer its economic value. Therefore duration of contracts need to be calculate properly so that it can balance the interests of both parties. Short term contracts may prevent the opportunity for international investors to get adequate return of investment, whereas long term contracts may prevent state/region opportunity for controlling its natural resources. It is often, public law provides certain range of permissable terms for certain international investment contracts.

There is a tendency for international investors to obtain contracts as long term as possible. Except, within permisable duration and with good business plan favourable also for state/region party, term should be not too long. At least for first duration. It is better not too long, but with possible extention. This will give opportunity to reconsider or renegotiation to keep face with new developments.

In practice, the provided in contract varies. For example, there is a contract with 30 years duration with possible extention of another 30 years. Another contract has 50 years duration with possible extention. There is also a contract for 80 years, without any possible extention.

\subsubsection{Choice of Foreign Law/International Law}

Principally, with few exeptions, parties based on doctrine of choice of law, are free to choice any law applicable for international contracts. How ever, when it comes to international investment contracts as specific field of contracts, it becomes questionable. This is because characteristic of the international investment contracts which apply not only on private law, but also public law. The interplay between private law and public law makes international invesment contracts unique. Therefore, it does not fully fall under private law which acqnowledge the doctrine of choice of law. ${ }^{\mathrm{xi}}$ To a certain extent, public law also applicable.

Party autonomy is a general and universal principle where the doctrin of choice of law is rooted. Based on this reasoning, doctrin of choice of law is also applicable for international investment contracts, as far as public law norms do not explicitly limit that application. Therefore as far as, there is no public law limits the application of choice law, the doctrine of choice of law is applicable. In other words, as general rule similar to other contracts, the doctrine of choice of law is applicable to international investment contracts, except where legislation has regulated differently.

Where there is no domestic law available, the doctrin of choice of law is applicable. Here, parties to international investment contracts based on conventional international private law doctrin can choose either domestic law of the house state or domestic law of the investors home state, or to certain extent also other national laws. Now, based on new development, parties can choose not only national or domestic law, but also transnational/international law. ${ }^{\text {xii }}$

In practice, various laws are chosen by parties. These laws include Indonesian law, the laws of investors home state, other national laws, and transnational/international law. The judgment is based on relative bargaining power of parties during negotiation process. As far as not limited by Indonesian national law, the barganing power dictates.

Choice of law other than national law of house country is unfavorable for that state/region. First, it is because national law generally represents public policy of that country. This public policy concern may different from one country to another. When state/region party choose national law of other country to be governing law for international investment contracts, the underlying policy on its own national law cannot be achieved. Second, state/region party understands more on the substantive contents of its national law rather than any other 
law. It will be more efficient for house state/region party negotiates to choose its own national law. This can provides more certainty and predictability for the state/region party.

\subsubsection{Stabilization}

On of risks faced by international investors when investing in foreign countries is the possibility of changing national laws during the investment term. The change of government may also change certain laws in that country. Even during the power of similar government, national laws may also change. This cannot be predicted when the international investment contracts are signed. Unpredictable change of law creates instability in the process of implementation of international investment contracts as long-term contracts.

To overcome this problem, contract drafters of the investors often create stabilization clause. The stabilization clause provides terms and conditions within the contract content which states that the contract clauses will be fully applicable during the contract term, including when contradicting new national law in house state/region is promulgated. As consequencies, change of law will not infuence the applicability of the signed contracts.

Sornarajah states "the aim of stabilization clause was to ensure that future changes in the legislation of host state did not vary the terms of the contract on the basis of which entry was made."xiii The stabilazation clause is a creative effort by international contract drafters to provide solution in preventing unanticipate risks for international investors. This is particularly important in relation to change of national tax law.

The stabilization clause often existed in international investment contracts, including in international investment contract of Aceh Province. Eventhough it is existed, but controversial. The controversial roots on whether on hierarchy, contract can be placed above national legislation.

According to general principle of law that specific law overides general law, lex specialis derogat legi generali. If contracts is assume as specific law and national legislation as generic law, based on that doctrin contract becomes preference. Here, contract is as lex specialis, whereas legislation is as lex generali. Therefore, the stabilization clause is applicable.

There is Indonesian expert who say that the principle of lex specialis derogat legi generali is not applicable in solving the confict issue between contract and national legislation. The reasoning is that it falls under another principle of law, that is lex posterior derogat legi inferiori. Here, legislation as lex superior, whereas contract as lex inferiori. Therefore, the stabilization clause is not applicable. According to Hikmahanto Juwana this principle is also suppoted by article 1320 and article 1337 ICC. These articles indicate that the validity of contract is depends on its fullment of requirements, among others, not contrary to national legislation, moral, and public policy. ${ }^{\text {xiv }}$

Inspite of it controvercy, stabilization clause is still favorable for international investors because it can be used as a preventive instrument in facing souverignity risk or noncommercial risk. The risk particularly arises in relation to use of state/region sovereignity in controlling its natural resources.$^{\mathrm{xv}}$ Through stabilization clause, the main purpose of contract for legal certainty can be achieved. How ever, to be wise, another main purpose needs also be condered, that is, achieveing justice. Both stability and flexibility aspects are needed to be considered in formulation, interpretaion, application, and enforcement of international investment contracts.

\subsection{Waiver of State/Region Immunity}

One of risks faced by international investors is the unclear role of a state/region in international relation. This because conventionally, a state/region can act both as sovereign actor (jure emperee) and as commercial actor (jure gestiones). According to doctrine, state/region can choose to act either fungtions. Therefore, the function of state/region in international relation can be divided. Eventhough, the doctrine has made possible the dual fungtions be seperated, in practice it may not be easy. Certain aspects of functions can interplay. It is not clear enough when a state/region acts in severeign capacity, and when it is act in commercial capacity.Based on the doctrine when a state/region acts on sovereign capacity, public law applicable. On the other hand, when a state/region act on commercial capacity, private law, here contract law, applicable. When a state/region performs sovereign act for public interest, it is immune from possibility to bring to civil court for civil wrong, such as nonperformance. Therefore civil court or arbitration center has no jurisdiction on that matter. This case falls under the jurisdiction of administrative court applying public law. On the other hand, when a state/region performs commercial act for commercial interest, it is similar to general public, who can be judged in civil court or arbitration center.

The interplay and unclear distiction between sovereign act and commercial act in international investment contracts create certain risks for international investors. To anticipate this problem, international contract drafters create an immunity clause as solution. Typical immunity clause states clearly that in application and intepretation of the contract, state/region act as commercial actor, and waives immunity. This clause implies that the governing of contract should be limited to commercial law. Therefore, when dispute occurs, the law applicable for that dispute is international contract law, as private law, and the case falls under the jurisdiction of civil courts or arbitration. 
The application of pure commercial law in the application of immunity clause may lessen the public interest of state/region in formation, performance, intepretaion, and enforcement of international investment contracts. Therefore, it's nature is unfavorable to state/region house party.

\subsection{Confidentiality/Intellectual Property Protection}

There are various forms of intellectual property. One of those is confidentiality/trade secrets. Others include copyrights, patent, trade mark, industrial design, integrated circuits, and plant variety protection. Each field of business transactions in international investment contracts has some connection to one or more intellectual property forms. Therefore, it is often in international investment contracts to also regulate confidentiality/intellectual property protection.

Intellectual property has been highly regulated both in national and international levels. How ever, the international investors still fills the need to also incorporate its protection within contractual system. This because in fact, the availability of the law, does not guarantee its implementation or enforcement. There often still intellectual property infringement, particularly in developing countries, including Indonesia. When it puts as an integral part of international investment contracts, the protection become stronger.

One of the most often form of intellectual property to be incorporated in international investment contracts is confidentiality/trade secrets. The term of confidentiality has broader connotation than the term of trade secrets. There are various ways of incorporation of confidentiality/intellectual property clause in international investment contracts.

First, narrower its meaning. If used, the narrower meaning still better or more favorable than boader meaning for house state/region party. This is because, there are still room for state/region to access certain kinds of data, information, knowledge, and technology. Second, broader its meaning. In broader meaning, there will be no or very limited room to do so. In fact, state/region party from developing countries need it for the purpose of developing its education and human resources.

An example of narrower meaning in an international investment contract states that not all data, information, knowledge, and technology is as confidential information, but only technical and commercial one. Another example states that if there is, international investors based on doctrine of proportionality will identify in writing that certain kinds of information has significant commercial value, as confidential information.

The narrower intepretation is consistent to UPICC. Article 2.16 UPICC provides that "Where information is given as confidential by one party in the cause of negotiation, the other party is under a duty to disclose that information or to use it improperly for its own purposes, whether or not a contract is subsequently concluded. Where appropriate, the remedy for breach of that duty may include compensation based on the benefit received by the other party.

An example of broader meaning in an international investment contracts states that all data, information, knowledge, and technology, except very few thing as stipulated under related laws, is consider as confidential information. This broader intepretation is unfavorable for developing countries, as state/region party. In fact, generally Indonesian intellectual property laws have already high standard of intellectual property protection. This high standard is unfavorable because most of intellectual property still owned by developed countries. Therefore, for the time being, the high protection sililar to those in developed countries, is not proportional.

The broader meaning of confidentiality/trade secret used is also inconsistent to the specific character of international investment contracts in which private law and public law coexistance. International investment contracts embrace together private comercial interests and public interestes, as regulated in various contract clauses. Therefore, different from pure commercial contract, international investment contracts maintains doctrine of transparancy and accountability. ${ }^{\text {xvi }}$ The doctrine of transparancy and accountabilty should become general rule in international investment contracts, because it contains public interest which need to be transparance and accountable based on wider principle of democracy. Except, in a very few limited things as regulate clearly under Act Number 14 of 2008 on Public Information Transparancy (APIT), the contracs should be transparance and accountable through public participation. APIT is as lex specialis, and Act Number 30 of 2000 on Trade Secrets (ATS) is as lex generali.

In the perspective of public law, there is also international trends for democratic conntry to put the doctrine of transparancy and accountability in higher level. Transparancy and accountabilty is as part of good govenance. This should also be applied to international investment contracts, as part of governance. This doctrin is important as part of public interest for controlling government actions in providing public affairs and services. Therefore, the ideal clause of confidentiality/intellectual property protection should be limited to certain kinds of data, information, knowledge, and technology, as regulate clearly in statutes or legislations. These exception includes privacy/personal data protection, trade secret, and state/region secret. These exception should be limited and regulated clearly in legislation. 


\subsection{Favorable Clauses}

Understanding unfavorable clauses is important for future consideration in amending or drafting new international investment contracts. It is specifically important during negotiation or renegotiation process. However, by understanding unfavorable clauses only, it is not enough in assessing balance or imbalance of the contracts. Other information needs also to be considered, that is, favorable clauses. Both unfavorable and favorable clauses need to be reviewed and compared each other for judging whether the whole contracts clauses are in balance.

Favorable clauses for house state/region party including, but not limited to as follows. First, choice of domestic law of house state/region party. Second, choice of international arbitration in house state/region party or in its neigboring countries. Third, choice of domestic language of house state/region party. Forth, short tem contract. Five, prohibition of assignment, except by consent of all parties. Six, renegotiation and adaptation in change of circumstances. Seven, transfer of knowledge and technology. Eight, recruitment of local workers. Eight, community development and environment protection.

When judging balance of the international investment contracts, particular attention how ever, needs to be given to transactional clauses. These clauses may be favorable for both parties, as a result of win to win transactional negotiation. How ever, proportionality of distributing rights and obligation between parties is important. These transactional clauses are the core content of international investment contracts. The clauses, including but not limited to, capital and financing of international investment joint venture company, composition of organ (boad of directors/board of commisioners) of the company, and profit sharing.

\section{CONCLUSION}

International investment contracts of Aceh Province, Indonesia, contains unfavorable clauses to house state/region party. These clauses, including but not limited to, choice of foreign/international arbitration abroad, licensing enrollment/facility, exclusivity of cooperation, long term contracts, choice of foreign/international law, and stabilization, waiver of immunity, and confidentiality/intellectual property protection. On the other hand, the contracts also contains favorable clauses to house state/region party. These clauses, including but not limited to, choice of domestic law of the house state/region, choice of international arbitration in house state/region or in its neighboring countries, choice of language of house state/region, short term contract, prohibition of assignment except with consent of all parties, renegotiation and adaptation in changes of circumstances, transfer of knowledge and technology, recruitment of local workers, and community development and environment protection. To see the balance of the contracts, the whole clause in each specific contract should be seperately analized. This made possible assessing balance of both unfavorable and favourable clauses. Besides reviewing the unfavorable and favourable clauses, specific attention needs to be given on transactional clauses of each contract. $^{\text {xii }}$ These clauses, including but not limited to, capital and financing of joint venture company, composition of board of directors and board of commissioners of joint venture company, and profit sharing.

Both understanding trends in international investment contracts in general and understanding each particular international investment contract is important for gaining knowledge useful as considerations in negotiation of renegotiation of similar contracts in the future. Without such understanding, it will not easy to gain balance or to rebalance the contracts. Balance and rebalance of international investment contracts will prevent future disputes or conflict with local community in house state/region. ${ }^{\text {xiii }}$ They will also support achievement of justice and fairness for state/region. Besides, performance of contracts will be more efficient and more effective, because it can reduce potential risks to international investors and made them possible to concentrate on business purposes. 


\section{REFERENCES}

[1] Gunawan Widjaya, Legal aspect in international business contracts: yuridical analysis on international sale of goods, Business Law Journal, 27 (4), 2008, 23-37.

[2] Mahmul Siregar, Legal certainty in international business transactions and its implication on Indonesia investment climate, Business Law Journal, 27 (4), 2008, 58-68.

[3] Zhaohua Meng, Party autonomy, private autonomy, and freedom of contracts, Canadian Social Science, 10 (86), 2014, 212-216.

[4] Taehee Ahn, application of pacta sunt servanda to state contracts between investors and host states and its implication for international investment regime. Availabe at: http://works.bepress.com/taehee_ahl/2 latest accessed January, 182016.

[5] Hanoch Dagan, Autonomy, pluralism, and contract law theory, Law and Contemporary Problems, 76 (19), 2013, 19-38.

[6] Julian Cardenas Garcia, Rebalancing oil contracts in Venezuela, Houston Journal of International Law, 32 (2), 2011, 236-300.

[7] Caroline Caufman, The principle of proportionality and European contract law, Maastricht European Law Institute Working Paper No. 2013/5, Faculty of Law, Maatsricht University.

[8] Bayu Hardjowahono, The principles of private international law (Bandung: PT Citra Aditya Bakti, 2013).

[9] Sutan Remi Syahdeini, Freedom of contract and equal protection for parties on bank loan contracts in Indonesia (Jakarta: Institut Bankir Indonesia, 1993).

[10] Ricardo Simanjuntak, Main Principles in International Commercial Contract, Business Law Journal, 27 (4), 2008, (13-22).

[11] Oyunchimeg Bordukh, Choice of law in state contracts in economic development sector-Is there party autonomy, doctoral diss., Bond University School of Law, Bond, 2008.

[12] Antonio R. Parra, Applicable law in investor-state arbitration, 2nd Annual Conf. on International Arbitration and Mediation (Investor-State Arbitration Panel), Foldham University Law School, 2007.

[13] M. Sornarajah, The international law on foreign investment (Cambridge, U.K.: Cambridge University Press, 2007).

[14] Hikmahanto Juwana, Kontrak Free Port, Harian Kompas, December 31, 2015.

[15] Kapwandi F. Lukanda, Renegotiating investment contracts: the case of mining contracts in Democratic Republic of Congo, Geo Mason J. Int'l Com. Law, 5 (3), 2014, 301-360.

[16] Yohannes Sogar Simamora, Contract law: principles of contract law for government procurements (Surabaya:LkasBang PRESSindo, 2009).

[17] Nanik Trihastuti, The law of contract of work: cooperation model of controlling Indonesian mining (Malang: Setara Press, 2013).

[18] Salim HS, The law of mining dispute settlement in Indonesia (Bandung: Pustaka Reka Cipta, 2013). 